\title{
The role of the adiponectin system in acute fasting-impaired mouse ovaries
}

\author{
Yingying Han*, Shuhao Zhang*, Haotong Zhuang, Sijie Fan, Jiayi Yang, Liwei Zhao, \\ Weidong Bao, Fuli Gao, Haolin Zhang, Zhengrong Yuan and Qiang Weng \\ College of Biological Science and Technology, Beijing Forestry University, Beijing, China \\ Correspondence should be addressed to Q Weng; Email: qiangweng@bjfu.edu.cn \\ *(Y Han and S Zhang contributed equally to this work)
}

\begin{abstract}
Adiponectin (ADIPOQ, encoded by Adipoq) is an important white adipose-derived adipokine linked to energy homeostasis and reproductive function. This study aims to reveal the expression and role of the adiponectin system in the ovaries under acute malnutrition. In this study, 48-h food deprivation significantly inhibited ovarian growth by suppressing cell proliferation and inducing cell apoptosis in the ovaries of gonadotrophin-primed immature mice. It was also accompanied by significantly decelerated basic metabolism (glucose, triacylglycerol and cholesterol), varied steroid hormones (follicle-stimulating hormone, luteinizing hormone and estradiol) and vanishment of the peri-ovarian fat. It is noteworthy that after acute fasting, the adiponectin levels in ovaries rather than in blood were significantly elevated. Immunohistochemical study demonstrated that adiponectin and its receptors (ADIPOR1 and ADIPOR2) primarily appeared in ovarian somatic and/or germ cells, and their protein expressions were upregulated in the ovaries from fasted mice. Further in vitro study verified that ADIPOR1/2 agonist obviously inhibited follicle-stimulating hormoneinduced oocyte meiotic resumption, while the antagonist significantly enhanced the percentage of oocyte maturation in the absence of follicle-stimulating hormone. Furthermore, the build up of peri-ovarian fat under physiological status in mice showed a positive correlation with both the hypertrophy of adipocytes and growth of ovaries. Taken together, these findings indicate that the upregulation of the adiponectin system disturbs the normal female reproductive function under the malnutrition status, and it may be associated with the loss of peri-ovarian fat depots.

Reproduction (2019) 158 429-440
\end{abstract}

\section{Introduction}

Female reproduction is considered as an energy consuming process, consisting of follicle development, oocyte maturation, ovulation, fertilization, parturition and lactation (Della Torre et al. 2014). Numerous studies have proved that either overnutrition or undernutrition affects normal reproductive function, leading to serious reproductive disorders (Yan et al. 2008, GarciaGarcia et al. 2011, Wu et al. 2015). Though obesity or overnutrition has aroused huge attentions worldwide, nutrient deficiency still plagues some low- and middleincome countries and is one of the greatest threats to the survival of wildlife. As reported, malnutrition disturbs ovarian development primarily by regulating hypothalamic-pituitary-gonadal (HPG) system and the involved biological activities (Li et al. 2014, Wang et al. 2016). Previous studies proved that acute food deprivation in mice would result in oocyte maturation inhibition and fertility reduction by regulating glucose transport and utilization (Han et al. 2012). However, whether other energy metabolism-related factors participate in this undernutrition-related ovarian impairment remains unclear.

White adipose tissue is a critical energy reservoir, consisting of various fat depots. A growing number of studies have indicated that fat present around abdominal viscera was different from that present in subcutaneous areas, depicting critical functions in inflammation, insulin resistance, type 2 diabetes as well as metabolic syndrome (Fontana et al. 2007, Hayashi et al. 2008). Rodents are most frequently used pre-clinical models of human metabolic diseases, whereas fat deposition in rodents is not identical to those in humans. Gonadal fat depot tissue refers to a major composition of visceral white fat in rodents, covering peri-ovarian adipose tissues (POAT) in females and epididymal fat depots in males. However, humans do not exhibit gonadal fat depots in their bodies. In most literature, the gonadal adipose tissues of rodents are considered as the corresponding visceral fat depots in humans. Recently, POAT in female mice was reported as the critical factor for ovarian development (Wang et al. 2017, 
Yang et al. 2018a). However, the function of POAT during female reproduction under malnutrition condition has been insufficiently known.

Besides energy storage, white adipose tissue is another vital endocrine organ that secretes a number of peptide hormones named adipokines (e.g., leptin, adiponectin, resistin and visfatin) (Scherer 2006), mostly linked with reproductive function. Among them, the $30 \mathrm{kDa}$ protein adiponectin is the most abundant adipokine being critical to glucose and lipid metabolism (Berg et al. 2001, Combs et al. 2004, Lihn et al. 2005). Unlike those of most adipokines, circulating adiponectin levels are inversely correlated with body mass index (Arita et al. 1999, Yamamoto et al. 2002). Adiponectin is primarily bound to its seven transmembrane protein receptors, ADIPOR1 and ADIPOR2, and all of those, forming the adiponectin system. Recent studies have found that adiponectin system expressed in various cerebral and reproductive tissues, including hypothalamus, pituitary, testis, ovary and placenta (Caminos et al. 2008, Tsatsanis et al. 2015, Sartori et al. 2016, Rak et al. 2017). Accumulating evidences indicated that hypoadiponectinemia in female was often associated with the metabolic dysregulations and reproductive dysfunctions (e.g., polycystic ovary syndrome) (Artimani et al. 2016). In ovary, adiponectin and its receptors are abundantly expressed, whereas the subcellular localizations are inconsistent in different species (Chabrolle et al. 2007a,b, 2009). It has been extensively proved that adiponectin inhibited proliferation or stimulated apoptosis in various mammalian cancer tissues (Diedonne et al. 2006, Nakayama et al. 2008). Adiponectin is found working in the processes of granulosa cells steroidogenesis and proliferation as well as oocyte maturation (Pierre et al. 2009, Maillard et al. 2010, Oliveira et al. 2017), whereas the effects of adiponectin on ovarian cell proliferation and apoptosis in female reproduction remain controversial.

In the current study, POAT was found closely associated with the ovarian development, and it disappeared in fasted immature female mice. Based on these findings, a hypothesis was proposed that the abnormality of ovarian function under malnutrition might be attributed to the loss of POAT and locally secreted adipokines. To test this hypothesis, the ovarian cell proliferation and apoptosis, blood metabolic and hormonal status, and ovarian adiponectin system were analyzed in the control and fasted mice. Furthermore, experiments to test the effects of ADIPOR $1 / 2$ agonist and antagonist on oocyte maturation in vitro were designed. Results obtained here will help gain more insights into the role of gonadal fat and adiponectin system in female reproduction, especially under the condition of energy metabolism imbalance.

\section{Materials and methods}

\section{Materials}

All chemicals used were purchased from Sigma-Aldrich Corp. unless otherwise indicated. Acrylamide, $N, N^{\prime}$-methylenebis-acrylamide, ammonium persulfate, glycine, SDS-PAGE pre-stained molecular weight standards, protein assay kits and horse radish peroxidase (HRP)-conjugated anti-rabbit and anti-mouse immunoglobulins (IgG) were obtained from Beijing ComWin Biotech Inc. (Beijing, China). The Click-iT Plus TUNEL Assay kit, SlowFade Gold Antifade Mountant with 4',6'-diamidino-2-phenylindole (DAPI), Medium 199 (M199) and TRIzol Reagent were purchased from Thermo Fisher Scientific Inc.. PVDF membranes and Immobilon Western Chemiluminescent HRP Substrate kit were from Millipore. Anti-rabbit PCNA, caspase-3 (CASP3), cleaved caspase-3 and PARP were purchased from Cell Signaling Technology Inc.. Diaminobenzidine, 2-(4-Benzoylphenoxy)- N-[1(phenylmenthyl)-4-piperidinyl] acetamide (ADIPOR agonist), anti-rabbit cyclin D1, D2, D3 (CCND1, CCND2, CCND3) and p15 polyclonal (CDKN2B) antibodies, anti-mouse p21 (CDKN1A), p27 (CDKN1B), $\beta$-actin (ACTB) and vinculin (VCL) monoclonal antibodies and anti-goat ADIPOR1 and ADIPOR2 antibodies were purchased from Santa Cruz Biotechnology Inc.. Anti-mouse adiponectin antibody was purchased from Abcam Inc.. AdipoRon (ADIPOR antagonist) was purchased from Phoenix Pharmaceuticals Inc. (Belmont, CA, USA). The mouse adiponectin ELISA kit was obtained from Cusabio Biotech Co. Ltd. (Wuhan, China).

\section{Animals}

Kunming female mice were purchased from China Institute of Laboratory Animal Science and were housed at a constant temperature $\left(24-26^{\circ} \mathrm{C}\right)$ and under a controlled light cycle (14-h light and 10-h darkness). All animal work was approved by the Policy on the Care and Use of Animals of the Ethics Committee of Beijing Forestry University.

To study the physiological growth of POAT, new born, 1, 2, 3 and 6-week-old mice were utilized; all these animals had ad libitum access to food and water. In the acute fasting experiment, immature female mice (3 weeks) were injected intraperitoneally with equine chorionic gonadotrophin (eCG, $5 \mathrm{IU} / \mathrm{mouse}$ ) for one time and killed by cervical dislocation $48 \mathrm{~h}$ later. In each experimental replicate, 30 mice were taken and divided into two groups (15 mice per group). One group was called the fasted group (F group), and the other group was called the control group (C group). The $\mathrm{C}$ group had ad libitum access to food and water, while the $F$ group mice were only given water ad libitum.

\section{Biochemical and hormonal assays}

Blood was collected and centrifuged at $825 \mathrm{~g}$ for $15 \mathrm{~min}$. Plasma was separated and transferred to a sterile tube and stored at $-80^{\circ} \mathrm{C}$ until assayed. Plasma and ovarian protein sample were used for detection of adiponectin levels by the mouse adiponectin ELISA kit according to the manufacturer's 
instructions. Absorbance measurements at $450 \mathrm{~nm}$ were performed using microplate spectrophotometer. Folliclestimulating hormone (FSH), luteinizing hormone (LH) and estrogen (E2) were assayed by direct solid-phase radioimmunoassay (RIA) using commercially available kits (Northern Biotechnology, Beijing, China). Concentration of glucose (GLU), triglyceride (TG), and cholesterol (CHO) were determined by Technicon RA-1000 using commercially available kits (Northern Biotechnology, Beijing, China). The intra- and inter-assay coefficients of variation were $10 \%$.

\section{Histology, immunohistochemistry and immunofluorescence}

Ovaries and POAT werefixed in cold $4 \%(\mathrm{w} / \mathrm{v})$ paraformaldehyde overnight. After fixation, tissues were dehydrated through an alcohol series and embedded in paraffin, and subsequently sectioned at $5 \mu \mathrm{m}$ using a microtome. After dewaxing and rehydration, sections were processed for hematoxylin-eosin (HE) staining, immunohistochemistry, immunofluorescence or TUNEL assay.

Tissues for HE staining were stained with hematoxylin for $5 \mathrm{~min}$ and eosin for $3 \mathrm{~min}$. Ovaries for immunohistochemistry were immersed in $10 \mathrm{mM}$ sodium citrate buffer $(\mathrm{pH} 6.0)$ and heated in a microwave oven for antigen retrieval. Thereafter, sections were incubation in $3 \% \mathrm{H}_{2} \mathrm{O}_{2}$ to inhibit endogenous peroxidase. Then, all tissues samples were rinsed in PBS and incubated with primary antibodies at $4^{\circ} \mathrm{C}$ at least for $16 \mathrm{~h}$. Nonimmune serum was used as a negative control. All primary antibodies were used at a dilution of 1:100. After washes in PBS, the sections were incubated with the biotinylated secondary antibody for $30 \mathrm{~min}$ at $37^{\circ} \mathrm{C}$, and then were rinsed in PBS. The staining was revealed by incubation with 3,3'-diminobenzidine tetrahydrochloride at room temperature. Finally, sections were counterstained with hematoxylin and observed under an Olympus BX51 microscope.

Sections for immunofluorescence were performed generally the same as immunohistochemistry described earlier, and normal donkey serum ( $5 \% \mathrm{v} / \mathrm{v})$ was used as blocking solution and fluorescein-conjugated donkey anti-goat or anti-mouse secondary antibodies were used at a dilution of 1:1000. Sudan black $(1 \% \mathrm{w} / \mathrm{v})$ was used to block the unspecific stain before counterstaining with DAPI and sections were observed under an Olympus BX51 fluorescence microscope.

\section{Real-time quantitative polymerase chain reaction analysis}

Total RNAs of ovaries were extracted using TRIzol Reagent according to the manufacturer's protocol, and then proceeded for cDNA generation. The mRNA abundance profiles of target genes were analyzed using real-time quantitative polymerase chain reaction (qPCR) and normalized against Actb mRNA. The primer pairs used in this study were listed in Table 1. The final data were analyzed by the $2^{-\Delta \Delta C T}$ method as previously mentioned (Livak \& Schmittgen 2001).

\section{Western blot}

Total proteins were extracted from the whole ovaries on ice in lysis buffer containing $10 \mu \mathrm{mol} / \mathrm{L}$ protease inhibitors. Homogenates were centrifuged at $12000 \mathrm{rpm}$ for $6 \mathrm{~min}$ at $4^{\circ} \mathrm{C}$, and the protein concentrations in the supernatants were determined using BCA protein assay kit. Aliquots of proteins were boiled in $100^{\circ} \mathrm{C}$ water for $10 \mathrm{~min}$ and then stored at $-20^{\circ} \mathrm{C}$ until analyzed. Protein extracts $(10 \sim 40 \mu \mathrm{g})$ were separated by SDS-PAGE with $5 \%(\mathrm{w} / \mathrm{v})$ stacking gel and $10 \%(\mathrm{w} / \mathrm{v})$ separating gel at $100 \mathrm{~V}$ for approximately $1.5 \mathrm{~h}$ and electrically transferred to $0.45 \mu \mathrm{m}$ PVDF membrane. The membranes were blocked with $5 \%$ non-fat dry milk in Tris-buffered saline (TBS) containing $0.1 \%$ Tween-20 (TBST) to block nonspecific binding for $2 \mathrm{~h}$ at room temperature, and then incubated with primary antibody in TBST with $0.5 \%$ non-fat milk at $4{ }^{\circ} \mathrm{C}$ at least $16 \mathrm{~h}$. After washes in TBST, the membranes were then incubated with HRP-conjugated secondary antibody for $2 \mathrm{~h}$ at room temperature. After washing again in TBST, the blots were visualized by Immobilon Western Chemiluminescent HRP Substrate kit, and protein content was determined by densitometrically scanning the exposed x-ray film. Primary antibodies were diluted as follows: ADIPOR1, 1:1000; ADIPOR2, 1:1000; adiponectin, 1:5000; CCND1, 1:800; CCND2,1:800; CCND3, 1:800; p15, 1:1000; p21, 1:1000; p27, 1:1000; PCNA, 1:2000; caspase-3, 1:2000; cleaved caspase-3, 1:1000; PARP, 1:1000; ACTB, 1:5000; and VCL, 1:5000.

\section{TUNEL assay}

Analysis of apoptotic cells in the ovaries was identified by the TUNEL technique according to the manufacturer's instructions. Paraffin-embedded ovaries sections $(5 \mu \mathrm{m})$ were deparaffinized and treated with paraformaldehyde $(4 \% \mathrm{w} / \mathrm{v})$ after washing with PBS, the slides were incubated with proteinase $\mathrm{K}$ at room temperature for $15 \mathrm{~min}$. After washing with PBS, the positive control was treated with Dnase I (1 unit Nasel diluted in $20 \mathrm{mmol} / \mathrm{L}$ Tris- $\mathrm{HCl}, \mathrm{pH} 8.4,2 \mathrm{mmol} / \mathrm{L}$ $\mathrm{MgCl}_{2}$ and $50 \mathrm{mmol} / \mathrm{L} \mathrm{KCl}$ for $30 \mathrm{~min}$ at room temperature). Then, all tissue samples were rinsed in PBS and incubated with $\mathrm{TdT}$ for $60 \mathrm{~min}$ at $37^{\circ} \mathrm{C}$ and Click-iT Plus reaction at $37^{\circ} \mathrm{C}$

Table 1 Primer sequences used for real-time quantitative polymerase chain reaction in the control and fasted mice.

\begin{tabular}{|c|c|c|c|}
\hline \multirow[b]{2}{*}{ Target gene } & \multicolumn{2}{|c|}{ Primer sequences } & \multirow[b]{2}{*}{ Product size (bp) } \\
\hline & Forward & Reverse & \\
\hline Сур19a1 & 5'-TCGTCGCAGAGTATCCAGAGGT-3' & 5'-CGCATGACCAAGTCCACAACAG-3' & 163 \\
\hline Star & 5'-GTGACGGTGGCACACGACTT-3' & 5'-TCTCСТTCСАTСТСТGTGGСTTCT-3' & 238 \\
\hline Esr1 & 5'-TGAAAGGCGGCATACGGAAAGAC-3' & 5'-GCATCCAACAAGGCACTGACCAT-3' & 214 \\
\hline Esr2 & 5'-CCACTGCCAATCATCGCTTCTCT-3' & 5'-TTCACAGGACCAGACACCGTAATG-3' & 229 \\
\hline Actb & 5'-GAGATTACTGCTCTGGCTCCTA-3' & 5'-GGACTCATCGTACTCCTGCTTG-3' & 150 \\
\hline
\end{tabular}


for 30 min after wash with PBS. Subsequently, sections were counterstained with DAPI and observed under the Olympus BX51 epifluorescence microscope.

\section{Cumulus cell-oocyte complexes (COCs) culture and maturation assay}

Ovaries were obtained from $46 \mathrm{~h}$ eCG-primed mice without fasting treatment, and then the ovaries were placed in hypoxanthine (HX)-M199 medium. COCs were collected by puncturing large antral follicles with hypodermic needle (27-gauge). COCs were washed three times and equal size with several layers of cumulus cells were collected. In each experiment, one group of COCs were cultured in an $80 \mu \mathrm{L}$ drop covered with mineral oil in $35 \mathrm{~mm}$ culture dish. Cultures were incubated in a humidified modular incubator at $37^{\circ} \mathrm{C}$ with $5 \% \mathrm{CO}_{2}$ for $22-24 \mathrm{~h}$. At the end of the culture period, oocytes were denuded mechanically by repeated pipetting to remove cumulus cells and the number of oocytes with a germinal vesicle (GV), germinal vesicle breakdown (GVBD) or polar body 1 (PB1) were determined under the inverted microscope.

\section{Statistical analysis}

All experiments were repeated a minimum of three times and results were presented as the mean \pm S.E.M. Data were analyzed by $t$-test or one-way ANOVA followed by Student-NewmanKeuls method (SNK, SigmaPlot, version 12.0 software). Significant differences were defined at $P$ values of $<0.05$.

\section{Results}

\section{Acute fasting suppressed basic metabolism, ovarian growth and POAT expansion}

As shown in Fig. 1A, the plasma GLU, CHO and TG concentrations in the acute fating group ( $F$ group) were markedly decreased compared with those in the control group (C group). Concurrently, mouse ovarian mass in the F group decreased significantly $(38 \%$ decrease, $P<0.05$, Fig. 1B). Consistent with the mentioned result, smaller ovarian size, looser and thinner cumulus cell layers in the F group mice were observed (Fig. 1C), and all the ovarian sections employed for HE staining were taken from the middle of tissues. The interesting finding is that the POAT completely vanished in the $\mathrm{F}$ group compared with that in the $C$ group (Fig. 1D). At the same time, the enlarged uterus in the $\mathrm{F}$ group was not observed in the $\mathrm{C}$ group after $48 \mathrm{~h}$ eCG treatment (Fig. 1D).

\section{Characteristics of POAT accumulation in vivo}

The physiological characteristic of the accumulation of per-ovarian adipose tissues is illustrated in Fig. 2A. The figure showed that POAT did not show up during the early postnatal life, for example, in the newborn,
A
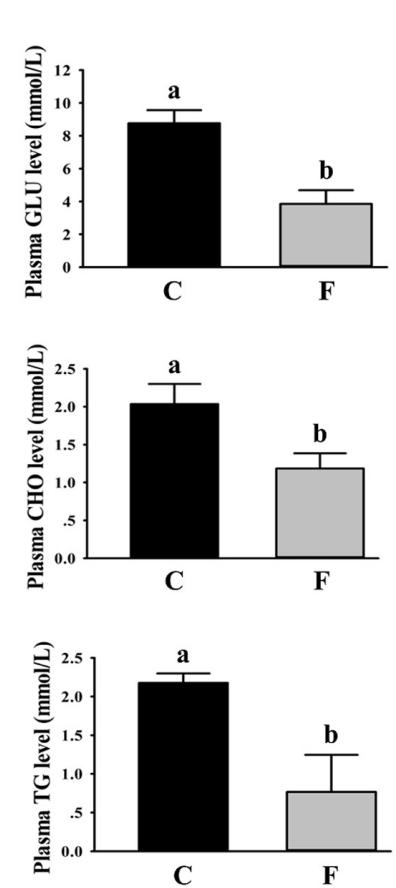

B

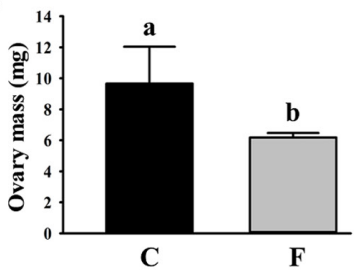

C
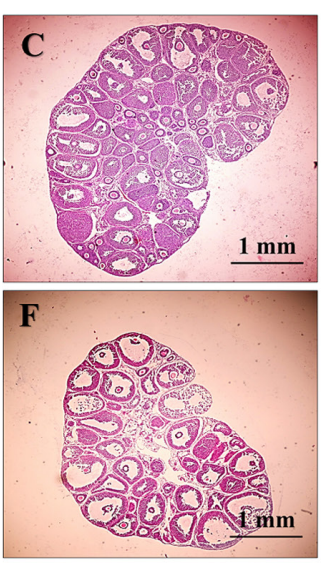

D

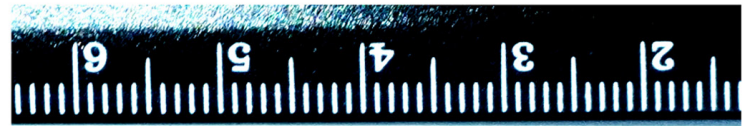

Control

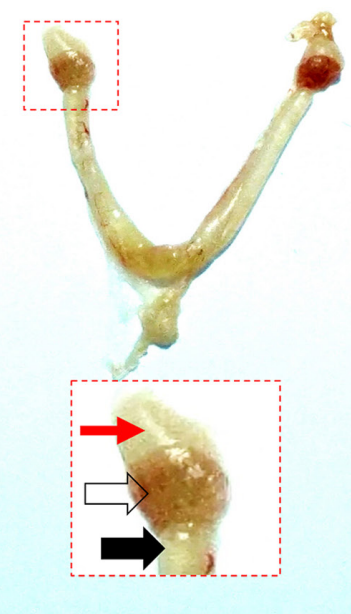

Fasting
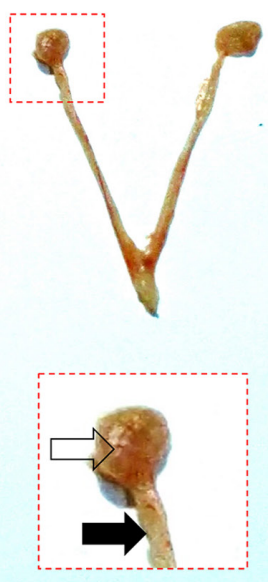

Figure 1 Effects of acute fasting on the basic metabolism, ovarian growth and POAT expansion. (A) Plasma glucose (GLU), cholesterol $(\mathrm{CHO})$ and triglyceride $(\mathrm{TG})$ concentrations in the mice from $\mathrm{F}$ and $\mathrm{C}$ groups. (B) Mouse ovarian mass in the $\mathrm{C}$ groups and $\mathrm{F}$ groups after 48-h food deprivation. (C) HE staining of paraffin-embedded sections of mouse ovaries from $\mathrm{C}$ and $\mathrm{F}$ groups. (D) Morphological characteristics of POAT and uterus between $\mathrm{C}$ and $\mathrm{F}$ groups. F group, the fasting group; $\mathrm{C}$ group, the control group. Scale bars represent $1 \mathrm{~mm}$. Error bars represent the mean \pm S.E.M. for three groups of experimental replicates (number of mice $n=30$ per experiment). The different letters denote a statistical difference at $P<0.05$ using two-sample $t$-test. 


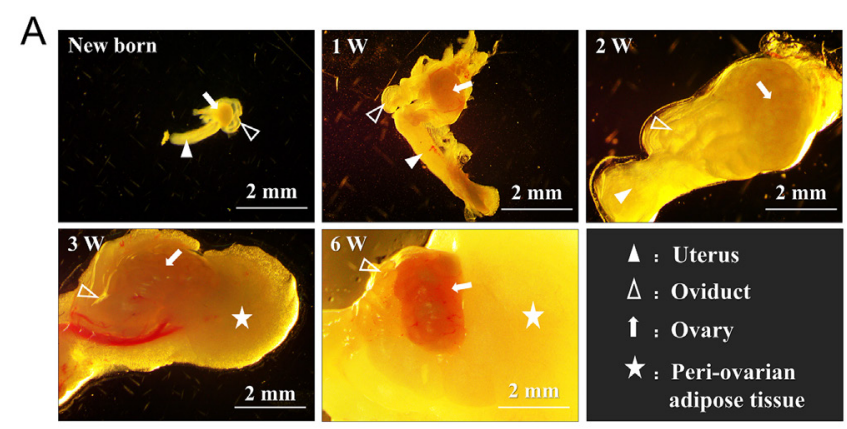

B
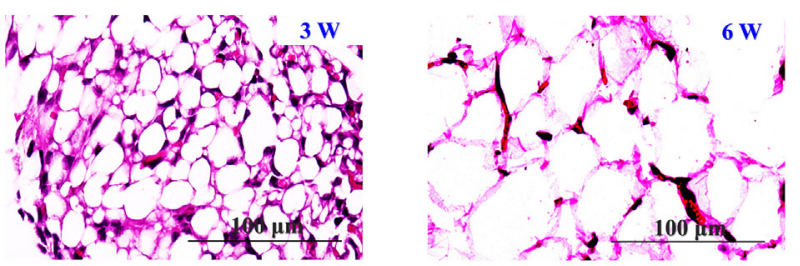

C
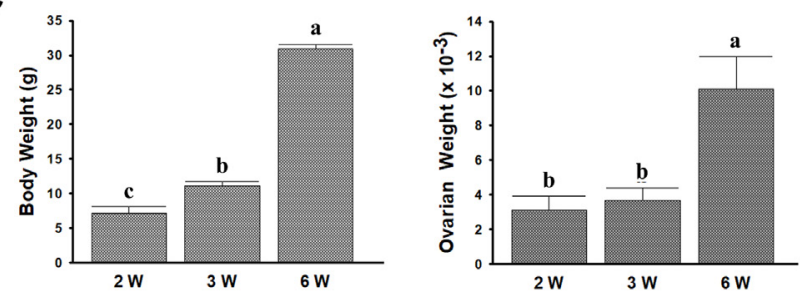

Figure 2 Characteristics of peri-ovarian adipose tissue (POAT) accumulation in vivo. (A) Photographs of the internal reproductive organs in female mice of the newborn, 1, 2, 3 and 6 weeks old. (B) Hematoxylin-eosin (HE) staining of paraffin-embedded sections of POAT from 3 and 6 weeks mice. (C) Mouse body and ovarian weights in female mice of 2, 3 and 6 weeks old. Scale bars represent $100 \mu \mathrm{m}$. Error bars represent the mean \pm S.E.M. for three groups of experimental replicates (number of mice $n=15$ per experiment). The different letters denote a statistical difference at $P<0.05$ using one-way ANOVA.

1 or 2-week mice; it started to build up in the mice around prepubescent period ( 3 weeks) and increased to maximum in the sexually mature stage (6 weeks). During the expansion of the adipose tissues, the hypertrophy of the white adipocytes occurred as shown in Fig. 2B. In the meantime, both the body and ovarian weights of mice were noticeably upregulated ( $P<0.05$, Fig. $2 \mathrm{C})$.

\section{Acute fasting stimulated cell apoptosis and suppressed cell proliferation in ovaries}

Cell apoptosis and proliferation of the ovaries of control and acute fasting groups were compared. As shown in Fig. $3 \mathrm{~A}$, the positive staining of TUNEL in granulosa and theca cells obviously increased in the ovaries of the acute-fasted mice. Though the protein expressions of caspase- 3 and PCNA in ovaries were not affected by acute fasting (Fig. 3B), immunohistochemical results suggested that PCNA in the antral follicles from the $\mathrm{F}$ group were obviously
A
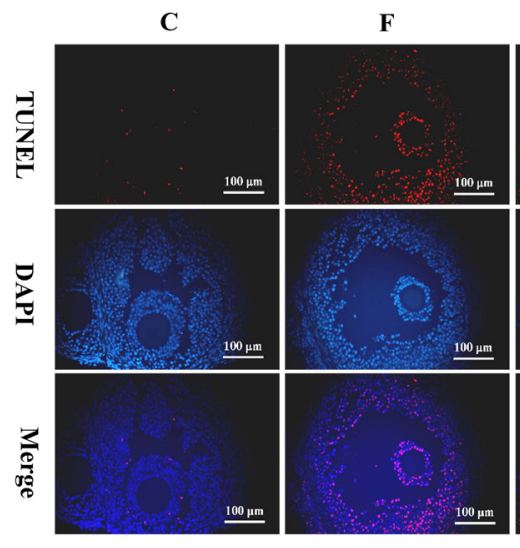

Positive

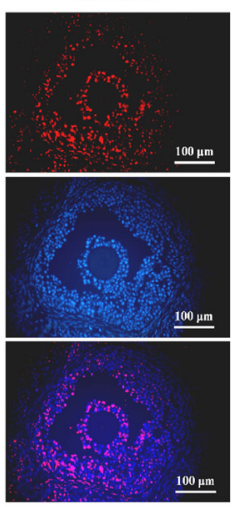

B
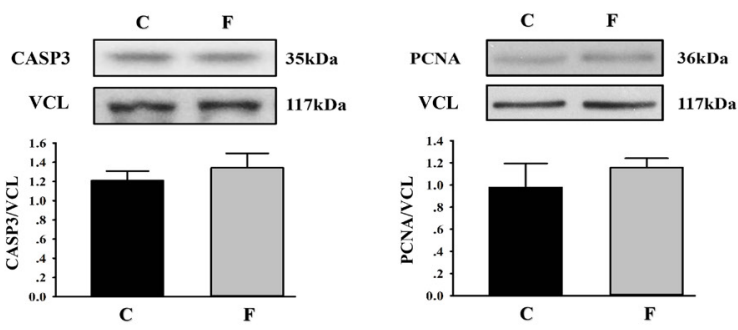

C
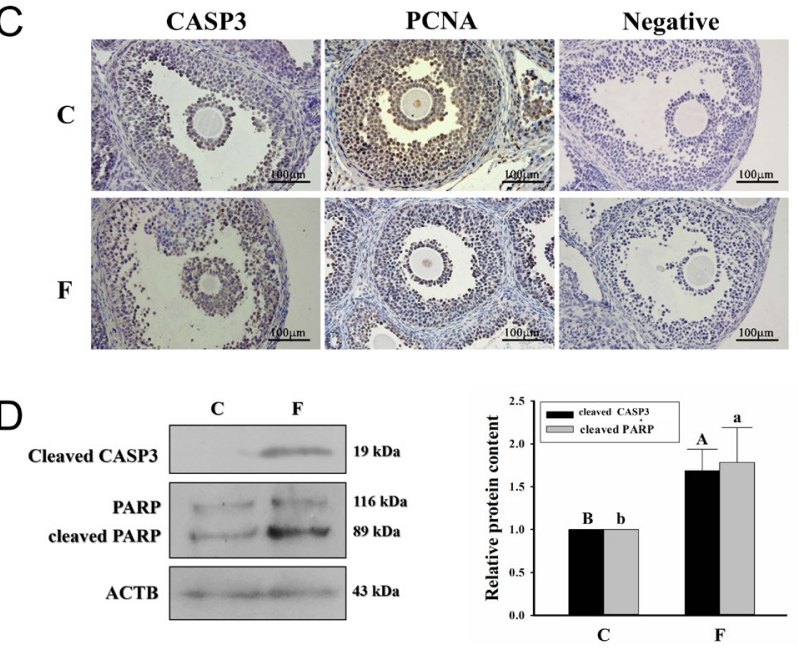

Figure 3 Effects of acute fasting on the ovarian cell growth. (A) Acute fasting increased the TUNEL-positive staining in the ovarian follicles of mice from $\mathrm{F}$ groups. (B) Proteins expression of caspase-3 (CASP3) and PCNA in mouse ovaries from $\mathrm{F}$ and $\mathrm{C}$ groups, and all protein contents were normalized against vinculin (VCL). (C) Immunolocalizations of caspase- 3 and PCNA in the mouse ovarian follicles from $\mathrm{F}$ and $\mathrm{C}$ groups. (D) Proteins expression of cleaved caspase- 3 and PARP in mouse ovaries from $\mathrm{F}$ and $\mathrm{C}$ groups, and all protein contents were normalized against $\beta$-actin (ACTB). F group, the fasting group; $\mathrm{C}$ group, the control group. Scale bars represent $100 \mu \mathrm{m}$. Error bars represent the mean \pm S.E.M. for three groups of experimental replicates, the number of mice was $n=30$ per experiment in (B). The different letters denote a statistical difference at $P<0.05$ using two-sample $t$-test.

downregulated (Fig. 3C). Moreover, in ovaries from fasted mice, the protein expression of both cleaved caspase 3 and PARP were significantly upregulated (Fig. 3D). 
The immunolocalizations for CCND1, CCND2 and CCND3 were primarily observed in granulosa cells of the antral follicles (Fig. 4A), and the ovarian protein expression of CCND3 (Fig. 4D) rather than that of CCND1 (Fig. 4B) or CCND2 (Fig. 4C) was inhibited in F group. Likewise, the cell cycle-inhibited protein CDKN2B, CDKN1A and CDKN1B were all detected in the granulosa cells of antral follicles (Fig. 5A), whereas the ovarian protein expression of CDKN2B (Fig. 5B) rather than that of CDKN1A (Fig. $5 \mathrm{C}$ ) or CDKN1B was significantly upregulated after acute fasting treatment (Fig. 5D).

\section{Acute fasting disturbed hormonal secretion and relative $m R N A$ expression}

According to the RIA results, acute fasting significantly downregulated blood $\mathrm{FSH}$ and $\mathrm{LH}$ concentrations but elevated E2 level (Fig. 6A). Consistent with the mentioned result, the mRNA expression levels of Cyp19a1 and Star in ovaries were significantly upregulated in F group (Fig. 6B). Besides, the $\mathrm{C}$ and $\mathrm{F}$ groups depicted no significant differences in ovarian Esr1 and Esr2 mRNA expression (Fig. 6C).

\section{Acute fasting enhanced the ovarian protein expression of adiponectin system}

Adiponectin concentrations in plasma and ovaries were ascertained using both ELISA and Western blot. As shown in Fig. 7A, 48-h food deprivation did not affect the plasma adiponectin content. Note that, the ovarian adiponectin level was significantly improved after the acute fasting $(P<0.05$, Fig. $7 \mathrm{~A})$. Moreover, the $\mathrm{F}$ group showed significantly up-regulated protein expressions of adiponectin (Fig. 7B), ADIPOR1 (Fig. 7C) and ADIPOR2 (Fig. 7D) in mouse ovaries, as compared with those in the $\mathrm{C}$ group. Figure 7E showed that adiponectin was expressed in both the germ cells (oocytes) and the somatic cells (granulosa cells and theca cells); ADIPOR1 was primarily located in theca cells, while ADIPOR2 was identified in granulosa cells.

\section{Effects of AdipoRs agonist and antagonist on oocyte maturation in vitro}

As shown in Fig. 8A, the high concentration $(\geq 10$ $\mu \mathrm{mol} / \mathrm{L}$ ) of 2-(4-Benzoylphenoxy)-N-[1-(phenylmenthyl)4-piperidinyl] acetamide (ADIPOR agonist) significantly suppressed $\mathrm{FSH}$-induced oocyte meiotic resumption (35\% decrease, $P<0.05$ ). Though AdipoRon (ADIPOR antagonist) had no statistical differences in $\mathrm{FSH}$-induced oocyte maturation, itfacilitated oocyte meiotic resumption without FSH addition (12\% increase, $P<0.05$, Fig. $8 \mathrm{~B}$ ). However, ADIPOR agonist and antagonist did not affect cumulus expansion (Fig. 8C and D).

\section{Discussion}

Undernutrition is associated with reproductive dysfunction. Previous studies proved that acute fasting
A
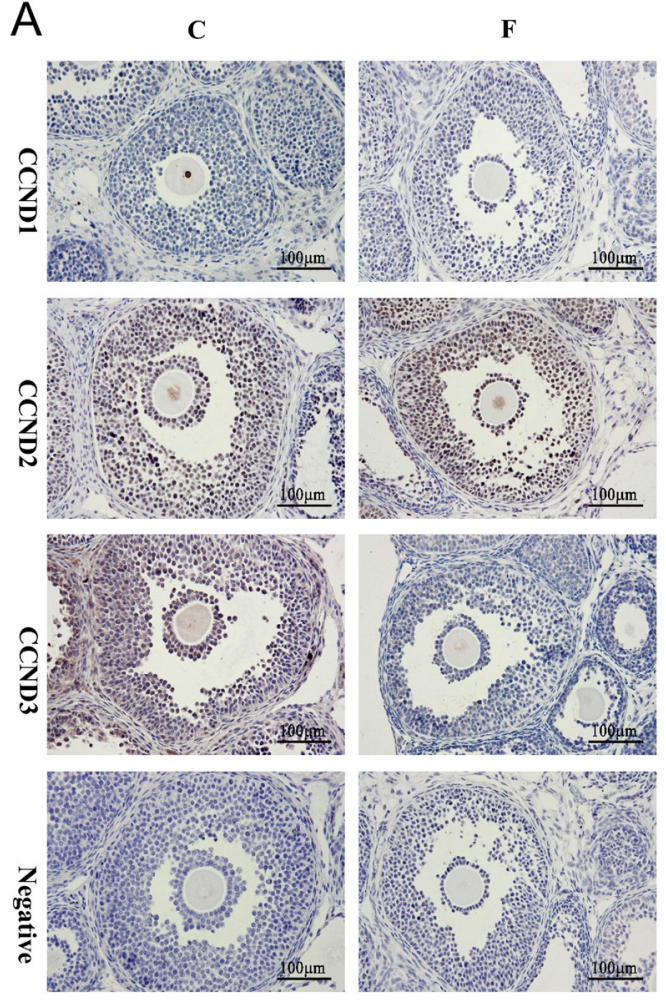

B

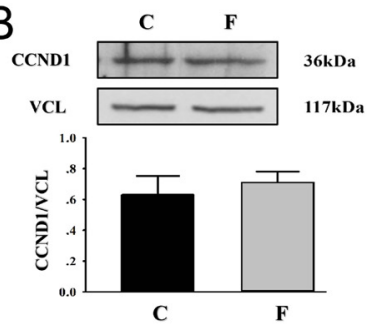

C

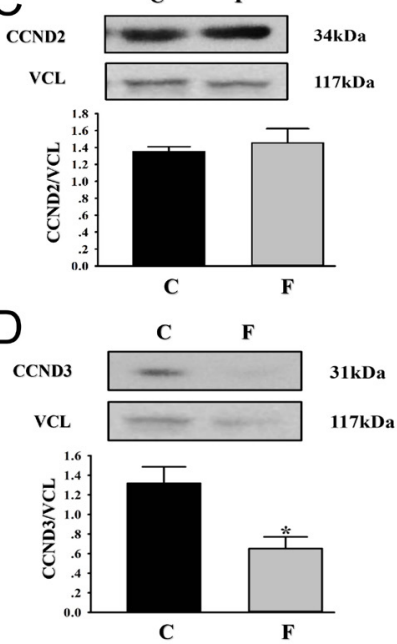

Figure 4 Effects of acute fasting on the expression of CCND1, CCND2 and CCND3 in ovaries. (A) Immunolocalizations of CCND1, CCND2 and CCND3 in the mouse ovarian follicles from $\mathrm{F}$ and $\mathrm{C}$ groups. (B, C and D) Proteins expression of CCND1, CCND2 and CCND3 in mouse ovaries from $\mathrm{F}$ and $\mathrm{C}$ groups, and all protein contents were normalized against vinculin (VCL). F group, the fasting group; $\mathrm{C}$ group, the control group. Scale bars represent $100 \mu \mathrm{m}$. Error bars represent the mean \pm S.E.M. for three groups of experimental replicates (number of mice $n=30$ per experiment). The different letters denote a statistical difference at $P<0.05$ using two-sample $t$-test. 
A
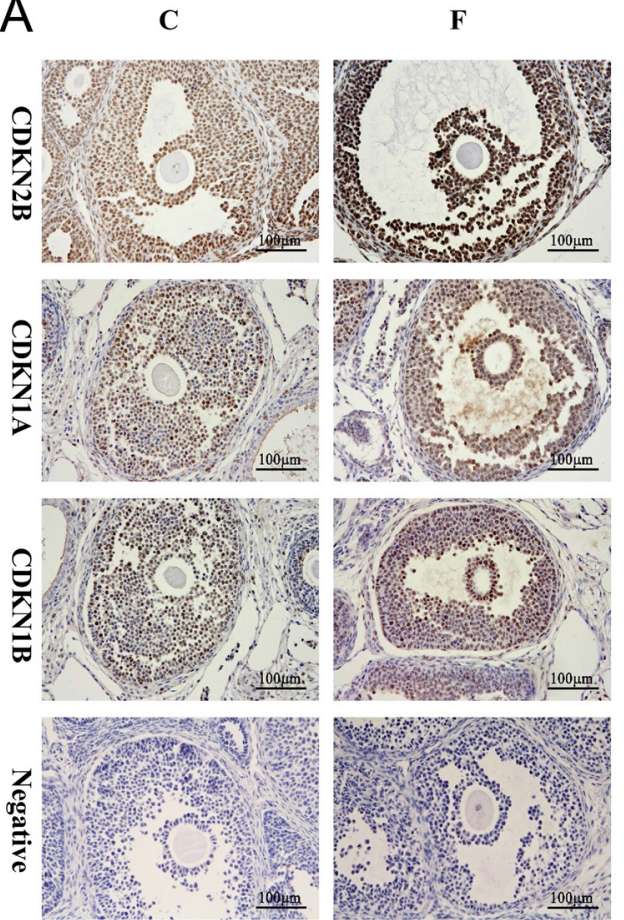

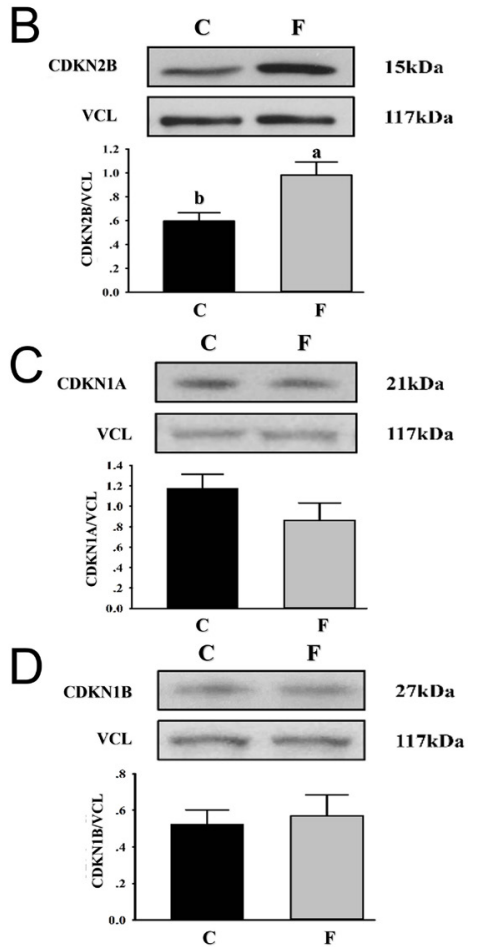

Figure 5 Effects of acute fasting on the expression of cyclin-dependent kinase inhibitors in mice ovaries. (A) Immunolocalizations of CDKN2B, CDKN1A and CDKN1B in the mouse ovarian follicles from $F$ and $C$ groups. ( $B, C$ and $D$ ) Proteins expression of CDKN2B, CDKN1A and CDKN1B in mouse ovaries from $\mathrm{F}$ and $\mathrm{C}$ groups, and all protein contents were normalized against vinculin (VCL). F group, the fasting group; $\mathrm{C}$ group, the control group. Scale bars represent $100 \mu \mathrm{m}$. Error bars represent the mean \pm S.E.M. for three groups of experimental replicates (number of mice $n=30$ per experiment). The different letters denote a statistical difference at $P<0.05$ using two-sample $t$-test.
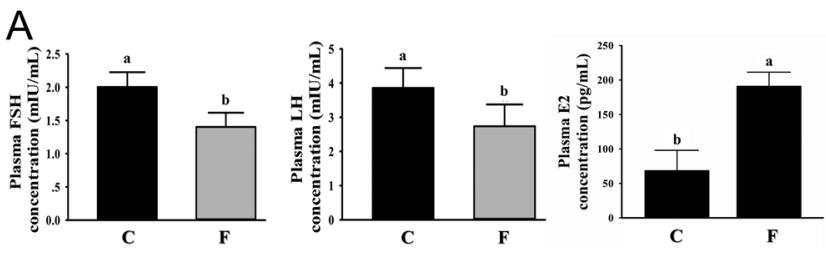

B
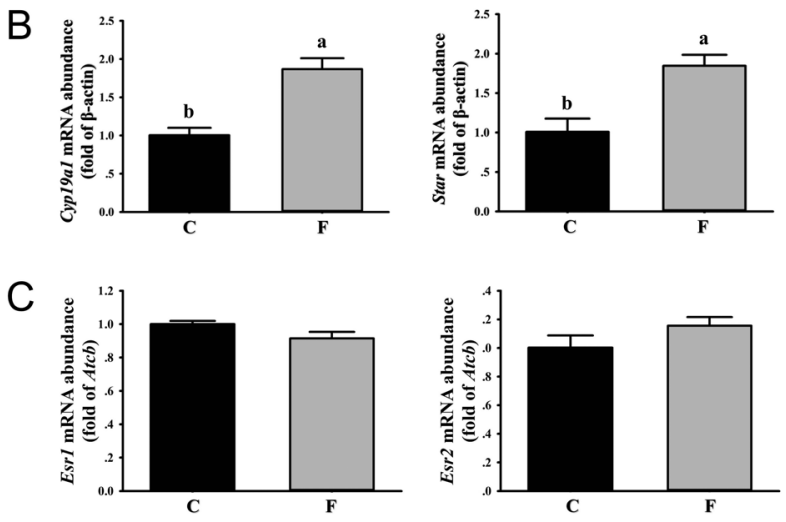

Figure 6 Effects of acute fasting on the hormonal secretion and relative mRNA expression. (A) Plasma FSH, LH and E2 concentrations in the mice from $\mathrm{H}$ and $\mathrm{C}$ groups. (B) mRNA expression of Cyp 19a 1 and Star in mouse ovaries from $\mathrm{F}$ and $\mathrm{C}$ groups, and the relative mRNA contents were normalized against Actb. (C) mRNA expression of Esr 1 and Esr2 in mouse ovaries from $\mathrm{F}$ and $\mathrm{C}$ groups, and the relative mRNA contents were normalized against $A c t b$. F group, the fasting group; $\mathrm{C}$ group, the control group. Scale bars represent $100 \mu \mathrm{m}$. Error bars represent the mean \pm S.E.M. for three groups of experimental replicates, the number of mice was $n=30$ per experiment in (A). The different letters denote a statistical difference at $P<0.05$ using two-sample $t$-test. suppresses oocyte maturation and reduces mouse fertility by inhibiting glucose transport and utilization (Yan et al. 2008, Han et al. 2012). In this study, the findings implied that the loss of POAT and upregulation of the adiponectin system might be link to the food deprivation-induced impairments of mouse ovaries.

In female mammals, successful reproduction is dependent on a highly complex and intricately regulated process of folliculogenesis. In this process, granulosa cell proliferation and differentiation are vital to follicular initiation, recruitment, selection, dominance, ovulation, and luteinization, while apoptosis of theca and granulosa cells induces follicular atresia. In this study, acute fasting significantly suppressed the protein expression of cyclin D3 in ovary, instead of those of cyclin D1 or cyclin D2. Cyclin D3 has been found to be upregulated in response to high fat diet in mice (Wu et al. 2015). We speculate that cyclin D3 may be sensitive to the nutritional condition and specially regulate mouse ovarian cell proliferation. In female, CDKN1A and CDKN1B are extensively studied cyclin-dependent kinase inhibitors (CDKIs), considered critical negative regulators for follicle development. However, neither protein CDKN1A nor CDKN1B was changed in ovaries after acute-fasted treatment. Besides, another CDKI, CDKN2B was significantly stimulated in the ovaries of fasted mice. To the best of our knowledge, the physiological role of CDKN2B in ovaries has been rarely reported (Cho et al. 2016), the role and the intricate mechanism of CDKN2B in female reproduction require further studies. Adiponectin has been reported inhibiting proliferation or stimulated apoptosis in different cancer cells (Diedonne et al. 2006, 


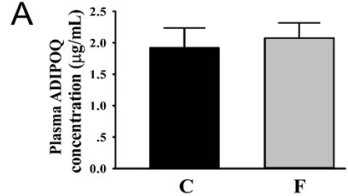

B
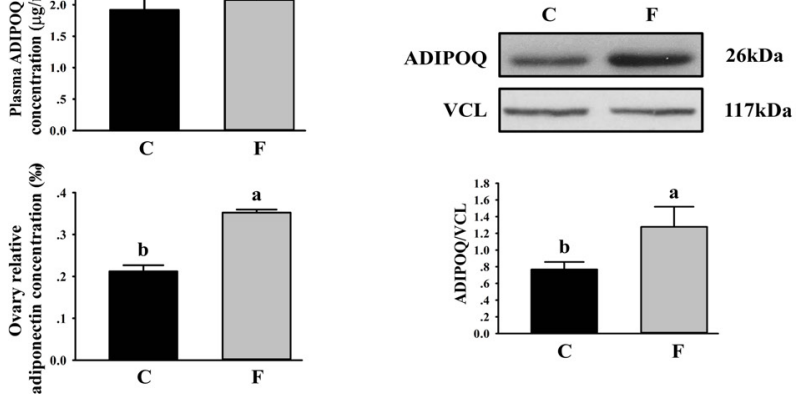

C
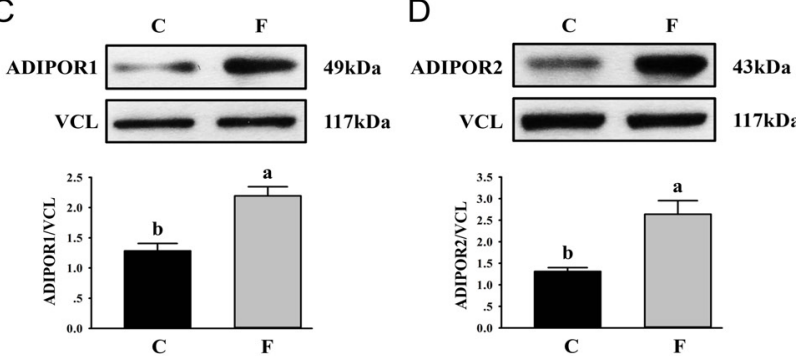

E
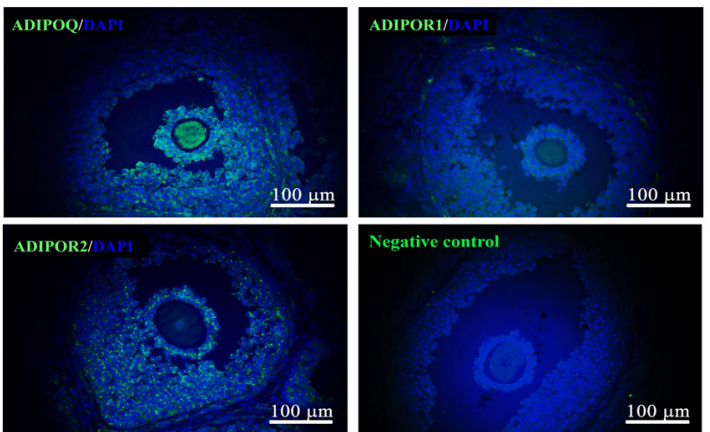

Figure 7 Effects of acute fasting on adiponectin system in mice. (A) The relative concentration of adiponectin in the plasma and ovaries of mice from $\mathrm{F}$ and $\mathrm{C}$ groups. (B, C, D and $\mathrm{E}$ ) Protein expressions of adiponectin (ADIPOQ), ADIPOR1 and ADIPOR2 in mouse ovaries from $\mathrm{F}$ and $\mathrm{C}$ groups, and all protein contents were normalized against vinculin (VCL). F group, the fasting group; C group, the control group; ADPN, adiponectin. Scale bars represent $100 \mu \mathrm{m}$. Error bars represent the mean \pm S.E.M. for three groups of experimental replicates, the number of mice was $n=30$ per experiment in (A). The different letters denote a statistical difference at $P<0.05$ using two-sample $t$-test.

Nakayama et al. 2008, Katira \& Tan 2016). In this study, it was also demonstrated that acute fastinginduced ovarian cell apoptosis by detecting more positive TUNEL staining in ovaries of mice. Caspase-3 is generally known as a major executioner protease participating in granulosa cell apoptosis during follicular atresia (Matsuda et al. 2012). Though the control and fasted groups displayed no significant difference in the protein expression of caspase-3, the upregulated active caspase-3 had been observed. To further verify the activation of caspase-3, the protein expression pattern of PARP, a classical substrate for active caspase-3, was also
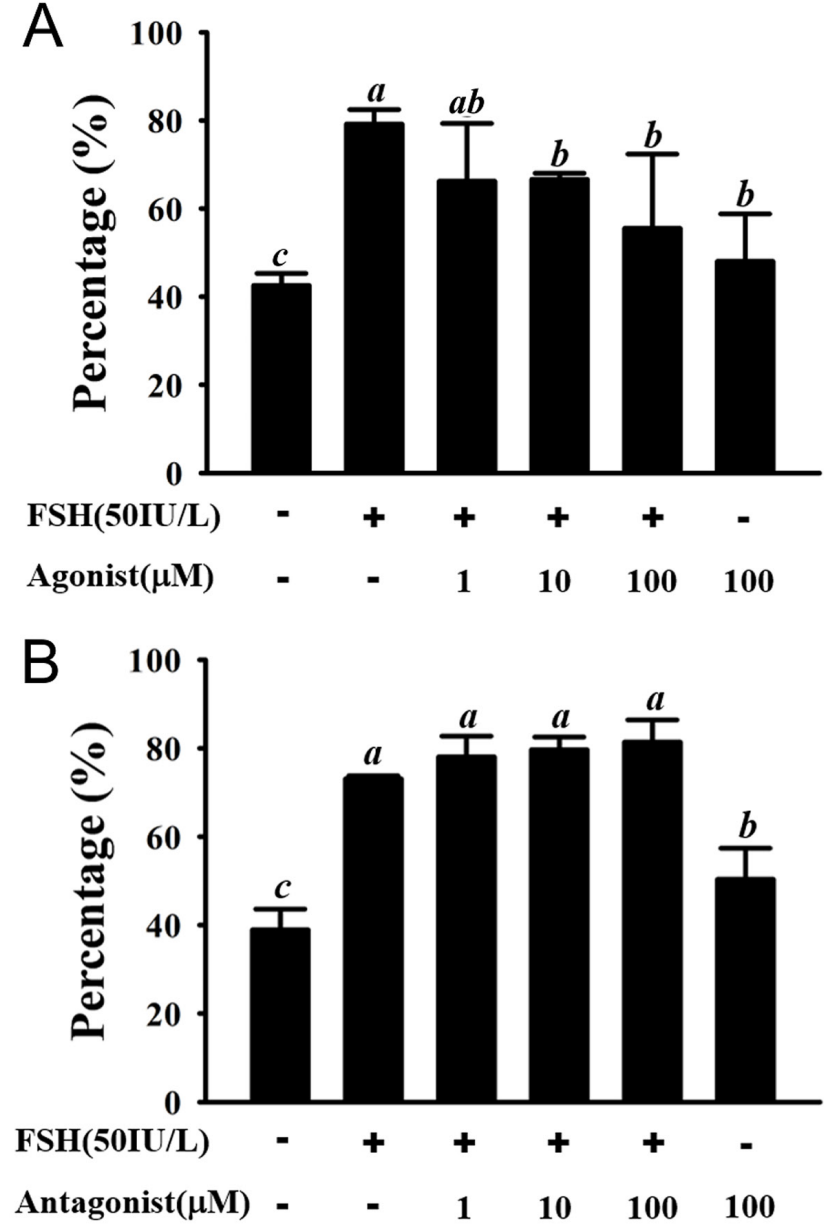

C

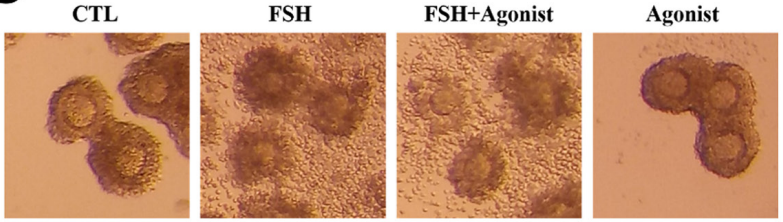

$\mathrm{D}$

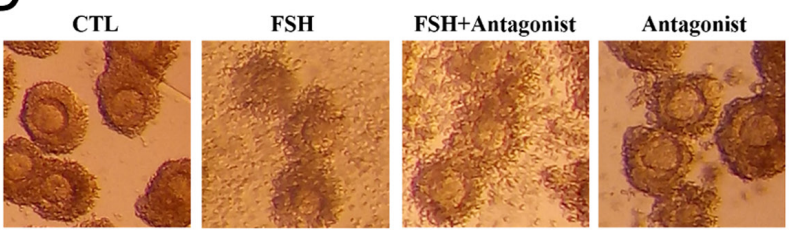

Figure 8 Effects of adiponectin receptors agonist and antagonist on cumulus cell-oocyte complexes (COCs) meiotic resumption and cumulus cell expansion. Mouse COCs isolated from eCG-primed mice were cultured in HX-M199 medium with or without FSH (50 IU/L), adiponectin receptors agonist, and antagonist. (A and B) The percentage of oocyte maturation (the ratio of GVBD and PB1) at the end of $22 \mathrm{~h}$ of culture. (C and D) Photographs of the cumulus cell expansion at the end of $22 \mathrm{~h}$ of culture. Error bars represent the mean \pm S.E.M. for three groups of experimental replicates, the number of COCs was $n=50$ per experiment. The different letters denote a statistical difference at $P<0.05$ using one-way ANOVA. 
detected (Henning et al. 2018). Likewise, the protein expression of cleaved PARP was significantly elevated in ovaries from $\mathrm{F}$ group. Based on these findings, it was concluded that acute fasting-induced ovarian cell apoptosis in a caspase-3-dependent manner. Thus, our results strongly demonstrated that acute fasting inhibited the mouse ovarian development by disturbing the process of ovarian cell proliferation and apoptosis.

In the ovary, the hypothalamic-pituitary-gonadal (HPG) axis and its secreted sex hormones act as the major regulator of cell growth and death. FSH and LH, two pituitary-secreted gonadotropins, are essential for promoting follicle growth, ovulation and the production of estrogen (E2) and progesterone (P4) (Richards 2018). In this study, noticeably decreased blood $\mathrm{FSH}$ and $\mathrm{LH}$ levels were ascertained in the acute fasting-induced POAT deficient mice, while the circulating E2 level was improved. The low levels of FSH and LH in acute-fasted mice might not be able to support big antral follicles and fully matured oocytes and could ultimately result in impaired ovarian development under malnutrition condition. Recently, Wang et al. have demonstrated that removal of POAT result in reduced FSH and E2 levels but enhanced LH content (Wang et al. 2017). Similarly, FSH displayed a corresponding decrease manner in the status of fasting-induced loss of POAT. However, the variations of E2 and LH were completely opposite to those reported by Wang et al., presumably due to the special treatment of acute fasting. Consistent with our findings, existing studies in rats and hamsters proved that food deprivation could improve plasma estrogen levels and suppress the pulsatile release of LH (Jones et al. 2002, Sarookhani et al. 2014). In vivo, the inhibiting effects of adiponectin and its paralog C1q/TNF-related protein 9 on FSH and $\mathrm{LH}$ were observed in various animals, including rat, Nile tilapia and porcine (Cheng et al. 2011, Kiezun et al. 2014, Yang et al. 2018a). It is suggested that the acute fasting-induced decrease in circulating $\mathrm{FSH}$ and LH may be attributed to the improvement of adiponectin levels in ovaries. Furthermore, studies in bovine ovaries reported that adiponectin suppressed the gene expression of Cyp11a and Cyp17a1 in theca cells (Dobrzyn et al. 2018), revealing that adiponectin might affect steroidogenesis. In this study, upregulated ovarian adiponectin was observed to be accompanied by decreased levels of circulation estrogen under acute fasting. The gene expression of Cyp19a1 and Star mRNA levels in ovaries was markedly upregulated in the fasted mice, suggesting the increased plasma E2 in fasted mice. It has been reported that E2 can act as a negative feedback regulator of LH secretion (Mostari et al. 2013, Munoz et al. 2017), probably leading to a decrease in the circulating LH level here. Besides, it was found that acute fasting did not affect the mRNA expression of Esr1 and Esr2 in ovaries, which further confirmed that the function of E2 would be enhanced under the acute fasting. Nevertheless, the role of increased estrogen levels remains unknown. It has been reported that the circulating estrogen participates in pain transmission and modulation of nociceptive responses (Coulombe et al. 2011), so it is speculated that the increase in estrogen might be a physiological protective mechanism against the damage derived from food deprivation.

Undernutrition strikingly interrupts mammalian basic metabolic status (Zha \& Qian 2017). In this study, acute fasting significantly downregulated the blood GLU, CHO and TG concentrations in female mice. White adipose tissue is the body's largest energy reservoir, consisting of various fat depots. It has been confirmed that fat distribution and function varied dramatically throughout life (Tchonia et al. 2010). Increasing researches (e.g., studies in perinodal, perivascular, pericardial, perirenal and POAT) have focused on the area of the site-specific properties and functions of white adipose tissues (Lohn et al. 2002, Pond 2003, Fox et al. 2009, Wang et al. 2017, Yang et al. 2018b). POAT is a major composition of visceral white adipose tissue; it plays special roles in inflammation and metabolic disorders of female rodents (Nteeba et al. 2013). In this study, it was revealed that mouse POAT did not accumulate in the early postnatal life, and it started to accumulate during prepubescence stage and expanded greatly in sexual maturity, revealing a positive relationship between the hypertrophy of adipocytes and growth of ovaries. According to the findings of Wang et al. and Yang et al., the removal of the POAT of mice exhibited abnormal estrous cyclicity, inhibited steroidogenesis, decreased fertility and less ovulated mature eggs (Wang et al. 2017, Yang et al. 2018b). Collectively, these findings implied that appropriate storage of POAT is essential for successful female reproduction. However, our knowledge remains insufficient about the detailed function and mechanism of POAT on female reproduction.

Adiponectin is a white adipose-secreted adipokine linking metabolism and reproduction; it is negatively correlated with adiposity and body mass index. In the present study, 48-h food deprivation significantly decreased the body weight of mice. However, there was no difference in the plasma adiponectin levels between the control and fasted groups. In fact, other rodent studies have also demonstrated that adiponectin levels were not affected by acute food deprivation or shortterm food restriction (Johansson et al. 2008, Turyn et al. 2008). Similarly, studies in humans have proposed that serum adiponectin concentrations remain remarkably stable during acute fasting (Gavrila et al. 2003, Imbeault et al. 2004). In this study, ELISA and Western blot results suggested that acute fasting significantly enhanced the ovarian rather than blood adiponectin content. Likewise, study in cattle showed that the adiponectin concentrations in serum and follicular fluid are not correlated (Heinz et al. 2015). Recently, different structural and functional properties of various white adipose tissue depots have been uncovered, including 
adipokine secretions (Hocking et al. 2010, Wronska \& Kmiec 2012). In humans and rodents, subcutaneous white adipose tissues are reported to be a major source of adiponectin (Wronska \& Kmiec 2012). Considering that the POAT completely vanished following food deprivation in this study, we suggest that the increase in endogenous adiponectin synthesis and/or its secretion in ovaries might be influenced by the peripheral adipose tissues through a paracrine and/or autocrine regulation. In brief, these findings encourage us to propose that there are adipose tissue depot-specific differences in the secretion of adiponectin in some specific organs and tissues.

Thus far, the role of adiponectin in female reproduction remains unclear, but its expression in reproductive tissues has been observed in humans and various animals. It is demonstrated that the localization of adiponectin and its receptors are abundant in oocyte, granulosa cells and theca cells of various animals, such as bovine, ewes and humans (Pierre et al. 2009, Maillard et al. 2010, Wang et al. 2016). Some researches indicated lower expressions of the adiponectin system in granulosa cells compared with that in theca cells (Tabandeh et al. 2010). In this study, we show that adiponectin was abundant in the whole ovary while ADIPOR1 was mainly expressed in theca cells and ADIPOR2 was mainly present in granulosa cells of mouse ovaries. The presence of the adiponectin in oocyte suggests a potential involvement in oocyte maturation. However, different findings have been reported on the function of adiponectin on oocyte maturation. For example, studies in goats and pigs demonstrate that adiponectin addition stimulates oocyte meiotic maturation (Chappaz et al. 2008, Oliveira et al. 2017), whereas bovine adiponectin has no influence on oocyte maturation (Maillard et al. 2010). In this study, we show that ADIPOR- agonist suppressed FSH-induced oocyte meiotic resumption in vitro, while the antagonist significantly enhanced oocyte meiotic resumption without FSH addition. These functional differences of adiponectin could possibly be due to the species-specific response of experimental animal. Furthermore, this study showed that food deprivation elevated ovarian expressions of both ADIPOR1 and ADIPOR2, suggesting that adiponectin may directly modulate mouse ovarian development. In granulosa cells, ADIPOR1 is reported to be the primary adiponectin receptor regulated by gonadotropin (Chabrolle et al. 2007b), and its knockdown in KGN cell lines leads to an arrest of cell proliferation and apoptosis phenotype. It seems that low concentration of circulating adiponectin is disadvantageous for ovarian cell growth. In contrast, it was demonstrated that adiponectin system was upregulated under low gonadotrophin (FSH and $\mathrm{LH}$ ) after undergoing food deprivation, implying that high concentration of adiponectin can also be disadvantageous. Collectively, all these suggest that the adiponectin system may participate in regulating ovarian development through the HPO axis under acute malnutrition.

In conclusion, this study suggests a specific upregulation of ovarian adiponectin system accompanied by a deficiency of POAT and impaired HPG axis-regulated ovarian development following 48-h food deprivation. These findings implicate that the POAT and adiponectin system may involve regulation of reproductive function through the paracrine/autocrine pathway. However, to reveal the role and mechanism of POAT and/or adiponecin system in ovarian physiology, further research is required.

\section{Declaration of interest}

The authors declare that there is no conflict of interest that could be perceived as prejudicing the impartiality of the research reported.

\section{Funding}

This work was supported by the Fundamental Research Funds for the Central Universities (NO. 2018ZY31); the National Natural Science Foundation of China (NO. 31500943); the Beijing Natural Science Foundation (NO. 8182039) and Collage Student Innovation and Entrepreneurship Training Program (NO. G201910022039).

\section{References}

Arita Y, Kihara S, Ouchi N, Takahashi M, Maeda K, Miyagawa J, Hotta K, Shimomura I, Nakamura T, Miyaoka K et al. 1999 Paradoxical decrease of an adipose-specific protein, adiponectin, in obesity. Biochemical and Biophysical Research Communications 425 560-564. (https://doi. org/10.1016/j.bbrc.2012.08.024)

Artimani T, Saidijam M, Aflatppnian R, Ashrafi M, Amiri I, Yavangi M, Soleimaniasl S, Shabab N, Karimi J \& Mehdizadeh M 2016 Downregulation of adiponectin system in granulosa cells and low levels of HMW adiponectin in PCOS. Journal of Assisted Reproduction and Genetics 33 101-110. (https://doi.org/10.1007/s10815-015-0620-1)

Berg AH, Combs TP, Du X, Brownlee M \& Scherer PE 2001 The adipocytesecreted protein Acrp30 enhances hepatic insulin action. Nature Medicine 7 947-953. (https://doi.org/10.1038/90992)

Caminos JE, Nogueiras R, Gaytan F, Pineda R, Gonzalez CR, Barreiro ML, Castano JP, Malagon MM, Pinilla L, Toppari J et al. 2008 Novel expression and direct effects of adiponectin in the rat testis. Endocrinology 149 3390-3402. (https://doi.org/10.1210/en.2007-1582)

Chabrolle C, Tosca L, Crochet S, Tesseraud S \& Dupont J 2007a Expression of adiponectin and its receptors (AdipoR1 and AdipoR2) in chicken ovary: potential role in ovarian steroidogenesis. Domestic Animal Endocrinology 33 480-487. (https://doi.org/10.1016/j.domaniend.2006.08.002)

Chabrolle C, Tosca L \& Dupont J 2007b Regulation of adiponectin and its receptors in rat ovary by human chorionic gonadotrophin treatment and potential involvement of adiponectin in granulosa cell steroidogenesis. Reproduction 133 719-731. (https://doi.org/10.1530/REP-06-0244)

Chabrolle C, Tosca L, Rame C, Lecomte P, Royere D \& Dupont J 2009 Adiponectin increases insulin-like growth factor I-induced progesterone and estradiol secretion in human granulosa cells. Fertility and Sterility $\mathbf{9 2}$ 1988-1996. (https://doi.org/10.1016/j.fertnstert.2008.09.008)

Chappaz E, Albornoz MS, Campos D, Che L, Palin MF, Murphy BD \& Bordignon V 2008 Adiponectin enhances in vitro development of swine embryos. Domestic Animal Endocrinology 35 198-207. (https://doi. org/10.1016/j.domaniend.2008.05.007) 
Cheng XB, Wen JP, Yang J, Yang Y, Ning G \& Li XY 2011 GnRH secretion is inhibited by adiponectin through activation of AMP-activated protein kinase and extracellular signal-regulated kinase. Endocrine 39 6-12. (https://doi.org/10.1007/s12020-010-9375-8)

Cho AR, Kim JY, Munkhbayer S, Shin CY \& Kwon O 2016 p21 upregulation in hair follicle stem cells is associated with telogen retention in aged mice. Experimental Dermatology 25 76-78. (https://doi.org/10.1111/ exd.12862)

Combs TP, Pajvani UB, Berg AH, Lin Y, Jelicks LA, Laplante M, Nawrocki AR, Rajala MW, Parlow AF, Cheeseboro L et al. 2004 A transgenic mouse with a deletion in the collagenous domain of adiponectin displays elevated circulating adiponectin and improved insulin sensitivity. Endocrinology 145 367-383. (https://doi.org/10.1210/en.2003-1068)

Coulombe MA, Spooner MF, Gaumond I, Carrier JC \& Marchand S 2011 Estrogen receptors beta and alpha have specific pro- and anti-nociceptive actions. Neuroscience $\mathbf{1 8 4}$ 172-182. (https://doi.org/10.1016/j. neuroscience.2011.02.057)

Della Torre S, Benedusi V, Fontana R \& Maggi A 2014 Energy metabolism and fertility: a balance preserved for female health. Nature Reviews Endocrinology 10 13-23. (https://doi.org/10.1038/nrendo.2013.203)

Diedonne MN, Bussiere M, Dos Santos E, Leneveu MC, Giudicelli Y \& Pecquery R 2006 Adiponectin mediates antiproliferative and apoptotic responses in human MCF7 breast cancer cells. Biochemical and Biophysical Research Communications 345 271-279. (https://doi. org/10.1016/j.bbrc.2006.04.076)

Dobrzyn K, Smolinska N, Kiezun M, Szeszko K, Rytelewska E, Kisielewska K, Gudelska M \& Kaminski T 2018 Adiponectin: a new regulator of female reproductive system. International Journal of Endocrinology 2018 7965071. (https://doi.org/10.1155/2018/7965071)

Fontana L, Eagon JC, Trujillo ME, Scherer PE \& Klein S 2007 Visceral fat adipokine secretion is associated with systemic inflammation in obese humans. Diabetes 56 1010-1013. (https://doi.org/10.2337/db06-1656)

Fox CS, Gona P, Hoffmann U, Porter SA, Salton CJ, Massaro JM, Levy D, Larson MG, D'agostino RB, Sr, O'Donnell CJ et al. 2009 Pericardial fat, intrathoracic fat, and measures of left ventricular structure and function: the Framingham Heart Study. Circulation 119 1586-1591. (https://doi. org/10.1161/CIRCULATIONAHA.108.828970)

Garcia-Garcia RM, Rebollar PG, Arias-Alvarez M, Sakr OG, BermejoAlvrez P, Brecchia G, Gutierrez-Adan A, Zerani M, Boiti C \& Lorenzo PL 2011 Acute fasting before conception affects metabolic and endocrine status without impacting follicle and oocyte development and embryo gene expression in the rabbit. Reproduction, Fertility, and Development 23 759-768. (https://doi.org/10.1071/RD10298)

Gavrila A, Chan JL, Yiannakouris N, Kontogianni M, Miller LC, Orlova C \& Mantzoros CS 2003 Serum adiponectin levels are inversely associated with overall and central fat distribution but are not directly regulated by acute fasting or leptin administration in humans: cross-sectional and interventional studies. Journal of Clinical Endocrinology and Metabolism 88 4823-4831. (https://doi.org/10.1210/jc.2003-030214)

Han Y, Yan J, Zhou J, Teng Z, Bian F, Guo M, Mao G, Li J, Wang J, Zhang M et al. 2012 Acute fasting decreases the expression of GLUT1 and glucose utilisation involved in mouse oocyte maturation and cumulus cell expansion. Reproduction, Fertility, and Development 24 733-742. (https://doi.org/10.1071/RD10301)

Hayashi T, Boyko EJ, Mcneely MJ, Leonetti DL, Kahn SE \& Fujimoto WY 2008 Visceral adiposity, not abdominal subcutaneous fat area, is associated with an increase in future insulin resistance in Japanese Americans. Diabetes 57 1269-1275. (https://doi.org/10.2337/db071378)

Heinz JF, Singh SP, Janowitz U, Hoelker M, Tesfaye D, Schellander K \& Sauerwein H 2015 Characterization of adiponectin concentrations and molecular weight forms in serum, seminal plasma, and ovarian follicular fluid from cattle. Theriogenology 83 326-333. (https://doi.org/10.1016/j. theriogenology.2014.06.030)

Henning RJ, Bourgeois M \& Harbison RD 2018 Poly(ADP-ribose) polymerase (PARP) and PARP inhibitors: mechanisms of action and role in cardiovascular disorders. Cardiovascular Toxicology 18 493-506. (https://doi.org/10.1007/s12012-018-9462-2)

Hocking SL, Wu LE, Guilhaus M, Chisholm DJ \& James DE 2010 Intrinsic depot-specific differences in the secretome of adipose tissue, preadipocytes, and adipose tissue-derived microvascular endothelial cells. Diabetes 59 3008-3016. (https://doi.org/10.2337/db10-0483)
Imbeault P, Pomerleau M, Harper ME \& Doucet E 2004 Unchanged fasting and postprandial adiponectin levels following a 4-day caloric restriction in young healthy men. Clinical Endocrinology 60 429-433. (https://doi. org/10.1111/j.1365-2265.2004.01997.x)

Johansson A, Fredriksson R, Winnergren S, Hulting AL, Schioth HB \& Lindblom J 2008 The relative impact of chronic food restriction and acute food deprivation on plasma hormone levels and hypothalamic neuropeptide expression. Peptides 29 1588-1595. (https://doi. org/10.1016/j.peptides.2008.04.018)

Jones JE, Pick RR \& Wade GN 2002 Food deprivation inhibits estrous behavior in hormone-treated Syrian hamsters despite elevated estradiol levels. Hormones and Behavior 41 316-320. (https://doi.org/10.1006/ hbeh.2002.1764)

Katira A \& Tan PH 2016 Evolving role of adiponectin in cancer-controversies and update. Cancer Biology and Medicine 13 101-119. (https://doi. org/10.28092/j.issn.2095-3941.2015.0092)

Kiezun M, Smolinska N, Maleszka A, Dobrzyn K, Szeszko K \& Kaminski T 2014 Adiponectin expression in the porcine pituitary during the estrous cycle and its effect on LH and FSH secretion. American Journal of Physiology-Endocrinology and Metabolism 307 E1038-E1046. (https:// doi.org/10.1152/ajpendo.00299.2014)

Li H, Song H, Huang M, Nie H, Wang Z \& Wang F 2014 Impact of food restriction on ovarian development, RFamide-related peptide-3 and the hypothalamic-pituitary-ovarian axis in pre-pubertal ewes. Reproduction in Domestic Animals 49 831-838. (https://doi.org/10.1111/rda.12375)

Lihn AS, Pedersen SB \& Richelsen B 2005 Adiponectin: action, regulation and association to insulin sensitivity. Obesity Reviews 6 13-21. (https:// doi.org/10.1111/j.1467-789X.2005.00159.x)

Livak KJ \& Schmittgen TD 2001 Analysis of relative gene expression data using real-time quantitative PCR and the 2(-Delta Delta C(T)) Method. Methods 25 402-408. (https://doi.org/10.1006/meth.2001.1262)

Lohn M, Dubrovska G, Lauterbach B, Luft FC, Gollasch M \& Sharma AM 2002 Periadventitial fat releases a vascular relaxing factor. FASEB Journal 16 1057-1063. (https://doi.org/10.1096/fj.02-0024com)

Maillard V, Uzbekova S, Guignot F, Perreau C, Rame C, CoypralCastel S \& Dupont J 2010 Effect of adiponectin on bovine granulosa cell steroidogenesis, oocyte maturation and embryo development. Reproductive Biology and Endocrinology 8 23. (https://doi. org/10.1186/1477-7827-8-23)

Matsuda F, Inoue N, Manabe N \& Ohkura S 2012 Follicular growth and atresia in mammalian ovaries: regulation by survival and death of granulosa cells. Journal of Reproduction and Development 58 44-50. (https://doi.org/10.1262/jrd.2011-012)

Mostari P, leda N, Deura C, Minabe S, Yamada S, Uenoyama Y, Maeda K \& Tsukamura H 2013 dynorphin-kappa Opioid receptor signaling partly mediates estrogen negative feedback effect on $\mathrm{LH}$ pulses in female rats. Journal of Reproduction and Development 59 266-272. (https://doi. org/10.1262/jrd.2012-193)

Munoz AL, Chesneau D, Hernandez H, Bedos M, Duarte G, Vielma J, Zarazaga LA, Chemineau P, Keller M \& Delgadillo JA 2017 Sexually active bucks counterbalance the seasonal negative feedback of estradiol on LH in ovariectomized goats. Domestic Animal Endocrinology 6042 49. (https://doi.org/10.1016/j.domaniend.2017.03.004)

Nteeba J, Ortinau LC, Perfield II JW \& Keating AF 2013 Diet-induced obesity alters immune cell infiltration and expression of inflammatory cytokine genes in mouse ovarianand peri-ovarian adipose depot tissues. Molecular Reproduction \& Development 80 948-958. (https://doi. org/10.1002/mrd.22231)

Nakayama S, Miyoshi Y, Ishihara H \& Noguchi S 2008 Growth-inhibitory effect of adiponectin via adiponectin receptor 1 on human breast cancer cells through inhibition of S-phase entry without inducing apoptosis. Breast Cancer Research and Treatment 112 405-410. (https://doi. org/10.1007/s10549-007-9874-3)

Oliveira BSP, Costa JAS, Gomes ET, Silva DMF, Torres SM, Monteiro PLJ, Jr, Santos Filho AS, Guerra MMP, Carneiro GF, Wischral A et al. 2017 Expression of adiponectin and its receptors (AdipoR1 and AdipoR2) in goat ovary and its effect on oocyte nuclear maturation in vitro. Theriogenology 104 127-133. (https://doi.org/10.1016/j. theriogenology.2017.08.013)

Pierre P, Froment P, Negre D, Rame C, Barateau V, Chabrolle C, Lecomte P \& Dupont J 2009 Role of adiponectin receptors, AdipoR1 and AdipoR2, in the steroidogenesis of the human granulosa tumor cell line, KGN. 
Human Reproduction 24 2890-2901. (https://doi.org/10.1093/humrep/ dep292)

Pond CM 2003 Paracrine interactions of mammalian adipose tissue. Journal of Experimental Zoology Part A: Comparative Experimental Biology 295 99-110. (https://doi.org/10.1002/jez.a.10215)

Rak A, Mellouk N, Froment P \& Dupont J 2017 Adiponectin and resistin: potential metabolic signals affecting hypothalamo-pituitary gonadal axis in females and males of different species. Reproduction 153 R215-R226. (https://doi.org/10.1530/REP-17-0002)

Richards JS 2018 The ovarian cycle. Vitamins and Hormones 107 1-25. (https://doi.org/10.1016/bs.vh.2018.01.009)

Sarookhani MR, Ghasemi-Dashkhasan E, Heidari-Oranjaghi N, AzhdariZarmehri H, Erami E \& Hosseini SS 2014 Effect of food deprivation on formalin-induced nociceptive behaviors and beta-endorphin and sex hormone concentration in rats. Iranian Biomedical Journal 18 107-113. (https://doi.org/10.6091/ibj.1212.2014)

Sartori C, Lazzeroni P, Merli S, Patianna VD, Viaroli F, Cirillo F, Amarri S \& Street ME 2016 From placenta to polycystic ovarian syndrome: the role of adipokines. Mediators of Inflammation 2016 4981916. (https://doi. org/10.1155/2016/4981916)

Scherer PE 2006 Adipose tissue: from lipid storage compartment to endocrine organ. Diabetes 55 1537-1545. (https://doi.org/10.2337/ db06-0263)

Tabandeh MR, Hosseini A, Saeb M, Kafi M \& Saeb S 2010 Changes in the gene expression of adiponectin and adiponectin receptors (AdipoR1 and AdipoR2) in ovarian follicular cells of dairy cow at different stages of development. Theriogenology 73 659-669. (https://doi.org/10.1016/j. theriogenology.2009.11.006)

Tchonia T, Morbeck DE, Von Zglinicki T, Van Deursen J, Lustgarten J, Scrable H, Khosla S, Jensen MD \& Kirkland JL 2010 Fat tissue, aging, and cellular senescence. Aging Cel/ 9 667-684. (https://doi.org/10.1111/ j.1474-9726.2010.00608.x)

Tsatsanis C, Dermitzaki E, Avgoustinaki P, Malliaraki N, Mytaras V \& Margioris AN 2015 The impact of adipose tissue-derived factors on the hypothalamic-pituitary-gonadal (HPG) axis. Hormones 14 549-562. (https://doi.org/10.14310/horm.2002.1649)

Turyn J, Korczynska J, Presler M, Stelmanska E, Goyke E \& Swierczynski J 2008 Up-regulation of rat adipose tissue adiponectin gene expression by long-term but not by short-term food restriction. Molecular and Cellular Biochemistry 312 185-191. (https://doi.org/10.1007/s11010008-9733-5)

Wang R, Kuang M, Nie H, Bai W, Sun L, Wang F, Mao D \& Wang Z 2016 Impact of food restriction on the expression of the adiponectin system and genes in the hypothalamic-pituitary-ovarian axis of pre-pubertal ewes. Reproduction in Domestic Animals 51 657-664. (https://doi. org/10.1111/rda.12727)

Wang HH, Cui Q, Zhang T, Guo L, Dong MZ, Hou Y, Wang ZB, Shen W, Ma JY \& Sun QY 2017 Removal of mouse ovary fat pad affects sex hormones, folliculogenesis and fertility. Journal of Endocrinology 232 155-164. (https://doi.org/10.1530/JOE-16-0174)

Wronska A \& Kmiec Z 2012 Structural and biochemical characteristics of various white adipose tissue depots. Acta Physiologica 205 194-208. (https://doi.org/10.1111/j.1748-1716.2012.02409.x)

Wu Y, Zhang Z, Liao X \& Wang Z 2015 High fat diet triggers cell cycle arrest and excessive apoptosis of granulosa cells during the follicular development. Biochemical and Biophysical Research Communications 466 599-605. (https://doi.org/10.1016/j.bbrc.2015.09.096)

Yamamoto $Y$, Hiirose H, Saito I, Tomita M, Taniyama M, Matsubara K, Okazaki Y, Ishii T, Nishikai K \& Saruta T 2002 Correlation of the adipocyte-derived protein adiponectin with insulin resistance index and serum high-density lipoprotein-cholesterol, independent of body mass index, in the Japanese population. Clinical Science 103 137-142. (https://doi.org/10.1042/cs1030137)

Yan J, Zhou B, Yang J, Tai P, Chen X, Zhang H, Zhang M \& Xia G 2008 Glucose can reverse the effects of acute fasting on mouse ovulation and oocyte maturation. Reproduction, Fertility, and Development 20 703712. (https://doi.org/10.1071/RD08034)

Yang G, Song Q, Sun C, Qin J, Jia J, Yuan X, Zhang Y \& Li W 2018a Ctrp9 and adiponectin receptors in Nile tilapia (Oreochromis niloticus): molecular cloning, tissue distribution and effects on reproductive genes. General and Comparative Endocrinology 265 160-173. (https://doi. org/10.1016/j.ygcen.2018.05.033)

Yang L, Chen L, Lu X, Tan A, Chen Y, Li Y, Peng X, Yuan S, Cai D \&Yu Y $2018 b$ Peri-ovarian adipose tissue contributes to intraovarian control during folliculogenesis in mice. Reproduction 156 133-144. (https://doi. org/10.1530/REP-18-0120)

Zha Y \& Qian Q 2017 Protein nutrition and malnutrition in CKD and ESRD. Nutrients 9 1-19. (https://doi.org/10.3390/nu9030208)

Received 25 February 2019

First decision 19 March 2019

Revised manuscript received 8 September 2019

Accepted 13 September 2019 